\author{
ANDRZEJ HUCHLA \\ ORCID: 0000-0002-3119-742X \\ Uniwersytet Wrocławski \\ Katedra Prawa Finansowego
}

\title{
ELEMENTY OCENY CHARAKTERU ZMIAN W PRAWIE PODATKOWYM
}

\begin{abstract}
Abstrakt: Istotne zmiany, jakie dokonywały się w polskim prawie podatkowym, mają na celu przede wszystkim zwiększenie wpływów budżetowych. Służą temu wprowadzanie nowych form obciążeń oraz uszczelnianie systemu podatkowego przy zastosowaniu kolejnych mechanizmów kontroli podatników (w tym wzorowanych na rozwiązaniach lub rekomendacjach o znaczeniu międzynarodowym). Odbywa się to jednak w drodze zbyt częstych nowelizacji, niepopartych analizą skuteczności wcześniejszych rozwiązań, z zatarciem granicy między zmianami a wprowadzaniem nowych podatków.
\end{abstract}

Słowa kluczowe: prawo podatkowe, zmiany prawa podatkowego, legislacja podatkowa

Ostatnie kilka lat to okres intensywnych modyfikacji w prawie podatkowym. Mają one bardzo zróżnicowany profil, zarówno jeżeli chodzi o znaczenie normatywne, jak i konstrukcję legislacyjną. Ze zrozumiałych względów zawsze bardziej eksponowane jest merytoryczne znaczenie zmian, istotnie niekiedy modyfikujących sytuację prawną adresatów norm. Jednak, co ciekawe, często dokonywane są analizy także strony formalnej wprowadzanych przepisów. Nie jest to tylko zabieg ograniczający się do oceny trybu i zewnętrznych efektów działania twórców nowych rozwiązań. Prawo podatkowe, będąc w ramach prawa finansowego gałęzią prawa publicznego, w sposób władczy kształtuje prawa i obowiązki we wrażliwej przecież sferze własności ${ }^{1}$. Oddziaływanie tego rodzaju powinno charakteryzować się wyjątkową starannością, tak aby - po pierwsze - zapewnić prawidłowe i efektywne funkcjonowanie systemu gromadzenia dochodów publicznych, a po drugie - ograniczyć administracyjną ingerencję w stosunki prawne i ekonomiczne. Są to zresztą w pewnym sensie dwie strony tego samego zagadnienia, ponieważ oba wspomniane cele mają zostać osiągnięte poprzez jednolite, odpo-

1 Zob.np. H. Filipczyk, Postulat pewności prawa w wykladni operatywnej prawa podatkowego, Warszawa 2013, s. 41. 
wiednie i spójne z tego punktu widzenia rozwiązania legislacyjne. Powszechnie akceptowana w prawie podatkowym zasada, że dozwolone jest tylko to, co prawo nakazuje, przewiduje lub akceptuje, oznacza obowiązek ustanowienia podstawy prawnej każdego działania - i podmiotów uprawnionych do ustalania oraz poboru podatków, i wszystkich kategorii podmiotów zobowiązanych. Z kolei nieobjęcie jakiegoś rodzaju zjawisk społecznych podatkowymi aktami prawnymi oznacza (niezależnie od przyczyn takiego stanu) pozostawienie ich w obszarze wolnym od opodatkowania ${ }^{2}$. Te same przepisy muszą więc godzić sprzeczne co do zasady interesy i spełniać swoją rolę niezależnie od zakresu regulacji. Ponieważ jednak w relacjach podatkowych to państwo kształtuje stan prawny, a jednocześnie decyduje o modelu wykonywania praw i obowiązków, na ogół więcej uwagi poświęca się potrzebie ochrony praw podatników i innych podmiotów zobowiązanych. Podstawowym, niejako pierwotnym instrumentem tej ochrony, jest więc właściwe ujęcie normatywne dające pewność zrozumienia i racjonalnego stosowania przepisów. Nie ma wątpliwości, że tylko w taki sposób można określać zakres obowiązków o charakterze podatkowym. Wynika to w szczególności z art. 84 Konstytucji Rzeczypospolitej Polskiej z dnia 2 kwietnia 1997 roku³, który obowiązek ponoszenia ciężarów i świadczeń publicznych, w tym podatków, wiąże $\mathrm{z}$ istnieniem zasad określonych $\mathrm{w}$ ustawie $\mathrm{e}^{4}$.

W tym kontekście wskazane zostaną zmiany układające się w możliwe do zauważenia tendencje. Są to więc pewne grupy zmian wykazujące mniej lub bardziej wyraźne cechy wspólne.

Najbardziej widoczne jest oczywiście wprowadzanie nowych podatków. W większości wypadków jest to działanie wyraźnie widoczne i niebudzące wątpliwości co do charakteru aktu prawnego. W ostatnim okresie były to: ustawa z dnia 15 stycznia 2016 roku o podatku od niektórych instytucji finansowych ${ }^{5}$ oraz ustawa z dnia 6 lipca 2016 roku o podatku od sprzedaży detalicznej ${ }^{6}$, a nieco wcześniej — ustawa z dnia 2 marca 2012 roku o podatku od wydobycia niektórych kopalin $^{7}$ i ustawa $\mathrm{z}$ dnia 25 lipca 2014 roku o specjalnym podatku węglowodorowym $^{8}$. Towarzyszyły im uzasadnienia fiskalne ${ }^{9}$, co w jednym wypadku może być o tyle zaskakujące, że projekt wniesiony został jako poselski.

2 R. Mastalski, Stosowanie prawa podatkowego, Warszawa 2008, s. 15.

${ }^{3}$ Dz.U. Nr 78, poz. 483 ze zm.

${ }^{4}$ Zob. A. Huchla, Ciężary $i$ świadczenia publiczne a podatki $w$ świetle art. 84 Konstytucji Rzeczypospolitej Polskiej, [w:] Konstytucyjne uwarunkowania tworzenia i stosowania prawa finansowego i podatkowego, red. P.J. Lewkowicz, J. Stankiewicz, Białystok 2010, s. 139.

5 Dz.U. z 2019 r. poz. 1836.

6 Dz.U. z 2019 r. poz. 1433 ze zm.

7 Dz.U. z 2020 r. poz. 452.

8 Dz.U. z 2018 r. poz. 2269.

9 W odniesieniu do ustaw uchwalonych w 2016 roku zob. uzasadnienie poselskiego projektu ustawy o podatku od niektórych instytucji finansowych z 3 grudnia 2015 roku, druk Sejmu VIII kadencji nr 75, s. 1, http://www.sejm.gov.pl/Sejm8.nsf/druk.xsp?nr=75 (dostęp: 1.05.2020); 
Pojawił się jednak jeszcze jeden podatek uregulowany ustawą z dnia 6 lipca 2016 roku o aktywizacji przemysłu okrętowego i przemysłów komplementarnych ${ }^{10}$. Pod tym tytułem, nonsensownym z punktu widzenia zawartości, kryją się przepisy dotyczące wyłącznie preferencyjnej, zryczałtowanej formy opodatkowania podatkiem dochodowym przedsiębiorców wykonujących działalność w zakresie budowy i przebudowy statków. Skutkiem takiego ujęcia był między innymi kłopot z ustaleniem nazwy podatku, dopiero nieco później utrwalonej jako „podatek od produkcji okrętowej”. Skądinąd zamiar podatkowego wsparcia sektora gospodarki morskiej jest dość dyskusyjny. Jeszcze wcześniejsza ustawa z dnia 14 sierpnia 2006 roku o podatku tonażowym ${ }^{11}$ umożliwiająca skorzystanie ze zryczałtowania podatku armatorom posłużyła w sumie kilku podatnikom i generowała wpływy budżetowe rzędu najwyżej kilkudziesięciu tysięcy złotych rocznie (obecnie w ogóle nie są one planowane). Dochody z podatku od produkcji okrętowej wstępnie szacowano na około $9 \mathrm{mln}$ zł (wobec $22 \mathrm{mln}$ zł opodatkowania niepreferencyjnego $)^{12}$; jak dotychczas nie były one wykazywane w statystykach. Kwestia ograniczonego kręgu podatników dotyczy także podatku od wydobycia niektórych kopalin utworzonego z myślą o jedynym w Polsce podmiocie dokonującym wydobycia miedzi i srebra (sytuacja zmieniła się dopiero po rozszerzeniu zakresu przedmiotowego ustawy).

Za to podatek węglowodorowy, który miał wejść w życie od 2020 roku, niedługo wcześniej został zniesiony ${ }^{13} \mathrm{~W}$ związku $\mathrm{z}$ malejącym zasięgiem prac nad wydobyciem gazu łupkowego, stanowiącego główny, zamierzony przedmiot opodatkowania ${ }^{14}$. Mimo że taka sekwencja zdarzeń wygląda dziwnie, akurat rezygnacja z potencjalnie nieefektywnego podatku jest całkiem racjonalna i zasługuje na aprobatę (szczególnie w kontekście uwag dotyczących podatku tonażowego).

Oprócz tego jednak inne nowe rodzaje świadczeń wprowadzano na drodze poszerzenia zakresu istniejących już podatków. Tryb ten dotyczył w obu podatkach dochodowych tak zwanego podatku od przychodów z budynków, podatku

uzasadnienie rządowego projektu ustawy o podatku od sprzedaży detalicznej z 15 czerwca 2016 roku, druk Sejmu VIII kadencji nr 615, s. 1, http://orka.sejm.gov.pl/Druki8ka.nsf/0/6E4B8F10C4A7AA01C1257FD3003ABA69/\%24File/615.pdf (dostęp: 1.05.2020)

10 Dz.U. z 2019 r. poz. 471 ze zm.

11 Dz.U. z 2019 r. poz. 31 ze zm.

12 Uzasadnienie rządowego projektu ustawy o podatku od aktywizacji przemysłu okrętowego i przemysłów komplementarnych z 31 maja 2016 roku, druk Sejmu VIII kadencji nr 557, http://orka. sejm.gov.pl/Druki8ka.nsf/0/CBDF20DEECC6849EC1257FC6003829E6/\%24File/557.pdf(dostęp: 1.05.2020).

13 Ustawą z dnia 11 września 2019 roku o uchyleniu ustawy o specjalnym podatku węglowodorowym oraz o zmianie niektórych ustaw (Dz.U. poz. 1978).

${ }^{14}$ Uzasadnienie rządowego projektu ustawy o uchyleniu ustawy o specjalnym podatku węglowodorowym oraz o zmianie niektórych ustaw z 25 lipca 2019 roku, druk Sejmu VIII kadencji nr 3718; http://www.sejm.gov.pl/Sejm8.nsf/druk.xsp?nr=3718 (dostęp: 1.05.2020). 
od dochodów z niezrealizowanych zysków, a w podatku dochodowym od osób fizycznych — daniny solidarnościowej.

Dwa pierwsze są, z uwagi na podstawę prawną, o tyle nietypowe, że ich konstrukcja w żaden sposób nie nawiązuje do dochodu ani nawet przychodu. Podatek od przychodów z budynków zakłada fikcję osiągania przychodów z budynków służących działalności gospodarczej równych wartości tych budynków (art. 24b ustawy z dnia 15 lutego 1992 roku o podatku dochodowym od osób prawnych ${ }^{15}$ i art. 30g ustawy z dnia 26 lipca 1991 roku o podatku dochodowym od osób fizycznych ${ }^{16}$ ), a pełniący rolę exit tax podatek od dochodów z niezrealizowanych zysków - fikcję osiągania przychodu o wartości przenoszonych za granicę składników majątku (art. 24f i n. ustawy o podatku dochodowym od osób prawnych i art. 30da i n. ustawy o podatku dochodowym od osób fizycznych). Są to więc konstrukcje zupełnie typowe dla podatków majątkowych. Uzasadnieniem powiązania podatkami dochodowymi jest co najwyżej usytuowanie ich jako dochody budżetu państwa (a nie gmin, jak inne podatki majątkowe). Ponadto, w odniesieniu do podatku od przychodów z budynków, zwraca uwagę powiązanie go z podatkiem dochodowym pobieranym na zasadach ogólnych w ten sposób, że pomniejsza się go o kwoty „Zwykłego” podatku, co podatkowi od budynków przydaje walor jakby minimalnej wysokości podatku na wypadek niewykazywania dochodów.

Danina solidarnościowa obciążająca dochody osób fizycznych (art. 30h ustawy o podatku dochodowym od osób fizycznych) może być traktowana albo jako dodatkowy podatek od dochodów przekraczających $1 \mathrm{mln}$ zł, albo jako zastosowanie kolejnej (trzeciej) stawki skali progresywnej. Tu z kolei rezygnacja z nazwy „podatek” na rzecz ogólniejszej („danina”) ma podstawę w postaci przekazania pochodzących z niej wpływów na Fundusz Solidarnościowy.

Tak czy inaczej, trzy ostatnio opisane rozwiązania łączy uniknięcie nazwania ich podatkami, zwłaszcza nowo wprowadzanymi. Można się w tym dopatrywać wymiaru jedynie psychologicznego, to jest stworzenia błędnego wrażenia nieistnienia dodatkowych instytucji prawa podatkowego.

Dodatkowo większość nowych instytucji ma swoje odpowiedniki w systemach podatkowych innych krajów, w szczególności Unii Europejskiej. Jako takie stanowią one głównie instrumenty zapobiegania unikania opodatkowania.

Zupełnie odrębna kategoria zmian to również działania zmierzające do uszczelnienia systemu podatkowego, ale polegające na wprowadzeniu szczegółowych tylko rozwiązań w poszczególnych podatkach. Szczegóły te mogą mieć różną wagę konstrukcyjną.

Nietypowy w tym kontekście jest przypadek rozszerzenia zakresu podmiotowego poprzez regulacje art. 15 ust. 1 pkt 7 i 8 ustawy z dnia 11 marca 2004

15 Dz.U. z 2019 r. poz. 865 ze zm.

16 Dz.U. z 2019 r. poz. 1387 ze zm. 
roku o podatku od towarów i usług ${ }^{17}$. Określiły one jako podatników nabywców towarów tak zwanych wrażliwych, którymi obrót relatywnie często związany był ze stwierdzonymi przypadkami oszustw podatkowych. Była to (nazywana odwrotnym obciążeniem) bardzo radykalna zmiana jednego z najważniejszych elementów konstrukcji - i to w kierunku dokładnie przeciwnym niż podstawowa zasada opodatkowania tym podatkiem podmiotu dokonującego sprzedaży. Usytuowanie opodatkowania w sferze nabycia ułatwiało kontrolowanie opodatkowania transakcji. Te przepisy uchylono w 2019 roku, ale tylko dlatego, że ich funkcję przejęło wprowadzenie (w odniesieniu do tych samych rodzajów transakcji) obowiązkowego mechanizmu podzielonej płatności z art. 108a ust. 1a tej samej usta$\mathrm{wy}^{18}$. Odwrotne obciążenie obowiązuje nadal w niektórych innych sytuacjach.

Przeważnie natomiast działania legislacyjne mające zminimalizować unikanie opodatkowania przybierają postać nakładanych na podatników (ewentualnie też inne podmioty zobowiązane) obowiązków o charakterze rejestracyjnym bądź sprawozdawczym. Ich zakres jest obecnie bardzo szeroki, a podstawą prawną mogą być przepisy zarówno szczegółowych ustaw podatkowych, jak i Ordynacji podatkowej ${ }^{19}$.

I tak właśnie w Ordynacji uregulowane są:

— jednolity plik kontrolny (art. 193a) będący przekazywanym organom podatkowym zbiorczym rejestrem transakcji podlegających opodatkowaniu podatkiem od towarów i usług;

- obowiązek informowania o schematach podatkowych (art. 86a i n.), czyli o zamierzonych lub realizowanych działaniach optymalizacyjnych;

- przeciwdziałanie wykorzystywaniu sektora finansowego do wyłudzeń finansowych (dział IIIB, art. 119zg i n.), polegające na bieżącym przetwarzaniu przez Krajową Administrację Skarbową pochodzących od instytucji finansowych zbiorczych zestawień transakcji przeprowadzanych za ich pośrednictwem;

— klauzula przeciwko unikaniu opodatkowania (dział IIIA, art. 119a i n.).

W tym zakresie szczególne kontrowersje dotyczą przeciwdziałania wykorzystywaniu sektora finansowego do wyłudzeń finansowych, ponieważ analiza danych i tym samym możliwa reakcja na nie organów skarbowych opiera się na nieudostępnionym publicznie systemie informatycznym. Nie wiadomo więc, jakie operacje finansowe są w tym trybie wychwytywane.

W ustawach o podatkach dochodowych charakterystyczne są zwłaszcza obowiązki w zakresie dokumentowania cen transferowych (art. 11k i n. ustawy o podatku dochodowym od osób prawnych i art. $23 \mathrm{w}$ i n. ustawy o podatku dochodowym od osób fizycznych), znacznie szersze niż wymagane w normalnych okolicznościach.

17 W brzmieniu ustalonym na podstawie Dz.U. z 2011 r. Nr 177, poz. 1054.

18 Dz.U. z 2020 r. poz. 106 ze zm.

19 Ustawa z dnia 29 sierpnia 1997 roku Ordynacja podatkowa (Dz.U. z 2019 r. poz. 900 ze zm.). 
Jeżeli chodzi o podatek od towarów i usług, to obowiązki w jego zakresie wynikają przede wszystkim z powołanych przepisów Ordynacji podatkowej. Mimo że zamieszczone $\mathrm{w}$ akcie ogólnego prawa podatkowego, praktycznie mają zastosowanie do transakcji objętych tym właśnie podatkiem ${ }^{20}$. Z kolei na przykład w ustawie z dnia 6 grudnia 2008 roku o podatku akcyzowym ${ }^{21}$ pojawił się obowiązek stałego śledzenia przemieszczania wyrobów akcyzowych za pomocą tak zwanego Systemu (art. 46q i n.).

Niezależnie od analizy treści zmian znaczenie może mieć sposób ich dokonywania. $Z$ oczywistych względów w tej sferze zwracają uwagę raczej błędy, jako że nie ma potrzeby koncentrować uwagi na sytuacjach niebudzących wątpliwości.

Poważne zastrzeżenia można zgłosić wobec sposobu wprowadzania do Ordynacji podatkowej przepisów o klauzuli przeciwko unikaniu opodatkowania instytucji w ogólnym prawie podatkowym ważnej, ale i, z uwagi na z konieczności ogólne ujęcie, kontrowersyjnej. Obszerny, w całości poświęcony klauzuli i postępowaniu z jej zastosowaniem, Dział IIIA został po dwóch latach obowiązywania (od 2019 roku) istotnie zmieniony i poszerzony. Mimo znacznych rozmiarów nowelizacji nie byłaby ona niczym dziwnym, gdyby nie towarzyszące jej okoliczności. Po pierwsze, przepisy te praktycznie nie były jeszcze stosowane ${ }^{22}$ i w związku z tym nie dało się ocenić ich działania w pierwotnym kształcie. Tymczasem dodano do nich między innymi zupełnie nowe, bardzo istotne rozwiązania, jak na przykład osobną, rozbudowaną procedurę cofnięcia skutków unikania opodatkowania. Charakterystyczne, że uzasadnienie projektu ustawy nowelizującej wyjątkowo szczegółowo, precyzyjnie i trafnie wypunktowało niedostatki wcześniejszej regulacji i niebezpieczeństwa z nimi związane ${ }^{23}$. Aby wykryć te błędy, nie trzeba było nawet czekać na zebranie doświadczeń z dopiero przeprowadzonych postępowań. Dodatkową ciekawostką był poziom językowy kompromitujący inicjatorów projektu ustawy ${ }^{24}$.

Innym, bardzo jaskrawym przykładem chaosu legislacyjnego są losy ustawy o podatku od sprzedaży detalicznej. W wyniku pytań i sporów o zgodność przepisów tej ustawy z prawem Unii Europejskiej (głównie w kontekście niedozwolonej pomocy publicznej) parokrotnie odraczano datę, od której uzyskane przychody

${ }^{20}$ Zob. K. Kopyściańska, E. Skwierczyńska, Zmiany w podatku od towarów i ustug w latach 2017-2018, Wrocław 2019, s. 81 n., 93 n., 137 n., 167 n.

21 Dz.U. z 2020 r. poz. 722.

22 W. Nykiel, Nowe przepisy dotyczace klauzuli przeciw unikaniu opodatkowania — wybrane aspekty legislacyjne, [w:] Wspótczesne problemy prawa podatkowego. Teoria i praktyka. Księa jubileuszowa dedykowana Profesorowi Bogumiłowi Brzezińskiemu, t. 1, red. J. Głuchowski et al., Warszawa 2019, s. 388-389.

${ }^{23}$ Uzasadnienie rządowego projektu ustawy o zmianie ustawy o podatku dochodowym od osób fizycznych, ustawy o podatku dochodowym od osób prawnych, ustawy — Ordynacja podatkowa oraz niektórych innych ustaw z 25 września 2018 roku, druk Sejmu VIII kadencji nr 2860, s. 59 n., http://www.sejm.gov.pl/Sejm8.nsf/druk.xsp?nr=2860 (dostęp: 1.05.2020).

24 W. Nykiel, op. cit., s. 387 i wskazane tam źródła. 
podlegają opodatkowaniu. Dopiero po orzeczeniu ${ }^{25}$ potwierdzającym możliwość wprowadzenia podatku ustalono obecne brzmienie art. 11a tej ustawy, zgodnie z którym będzie miał on zastosowanie do przychodów uzyskiwanych od 1 lipca 2020 roku. Okazało się tym samym, że konstrukcja podatku została określona prawidłowo. Na pewno jednak niewłaściwa była kolejność działań — wyjaśnić tak istotne wątpliwości należało stanowczo jeszcze przed uchwaleniem ustawy.

Powyższe uwagi dotyczą niewielkiego tylko wycinka ustawodawstwa podatkowego. Skoncentrowały się na podatkach będących dochodami budżetu państwa, $i$ to tych najważniejszych (obrotowych i dochodowych). Nawet w tym zakresie poruszone zostały jedynie niektóre zagadnienia. Tymczasem podobne analizy można odnieść też do pozostałych podatków, innych niż omówione dotychczas przepisów Ordynacji podatkowej i innych aktów ogólnego prawa podatkowego, przepisów wykonawczych, a nawet podatkowych uchwał rad gmin ${ }^{26}$. Są one zresztą już prowadzone, $\mathrm{z}$ efektem w postaci bardzo różnorodnych ustaleń.

W opisanym zakresie widoczne są pewne charakterystyczne tendencje przedstawione poniżej w zakresie może nawet nieco wykraczającym poza wcześniej omówione instytucje i rozwiązania.

Jeżeli chodzi o merytoryczne znaczenie dokonywanych zmian, to przede wszystkim mają one na celu zwiększenie dochodów budżetu finansującego coraz szybciej rosnące wydatki publiczne. Służą temu zabiegi zmierzające do uszczelnienia systemu podatkowego. Szczegółowymi jego instrumentami są głównie kolejne instytucje prawne zapewniające zwiększoną kontrolę nad zachowaniami podatników. Polegają one najczęściej na nakładaniu na podatników dodatkowych obowiązków o charakterze sprawozdawczym, nierzadko bardzo zaawansowanych technicznie i uciążliwych. W ten sposób obciąża się ich działaniami, których efektem jest dostarczanie administracji podatkowej ogromnego zestawu danych przetwarzanych w ramach weryfikacji prawidłowości rozliczeń i innych czynności. Z całą pewnością jest to wyraz braku zaufania wobec podatników i uznania ich za podmioty niedostatecznie wiarygodne w zakresie spoczywających na nich obowiązków, zwłaszcza samoobliczania zobowiązań podatkowych. Tymczasem wszystkie te ustalenia mogą być poczynione przez organy podatkowe także w toku postępowania dowodowego przy okazji odpowiednich procedur (postępowania podatkowego oraz trybów kontrolnych), ale w zakresie indywidualnie oznaczonym na potrzeby konkretnej sprawy. Skoro ostatnio kładzie się nacisk na automatyczne gromadzenie wszystkich danych, można dopatrywać się w tym także swoistego braku zaufania do sprawności i skuteczności organów podatkowych, jako wymagających wspomagania informacyjnego od samych podatników. Zmieniają się więc tradycyjnie rozumiane role zainteresowanych podmiotów, a przede wszystkim profil działania organów podatkowych.

25 Wyrok Sądu Unii Europejskiej z dnia 16 maja 2019 roku w sprawach T-836/16 i T-624/17, EU:T:2019:338.

26 Zob. L. Etel, Uchwaly podatkowe samorzadu terytorialnego, Białystok 2004, s. 268 n.

Przegląd Prawa i Administracji CXX, 2020, cz. 1 i 2

(C) for this edition by CNS 
Nie zmienia tej oceny spostrzeżenie, że niektóre, a może nawet większość z takich zmian, wywodzą się z doświadczeń innych krajów, są rekomendowane przez instytucje międzynarodowe albo wprowadzane jako wspólne w Unii Europejskiej. Zrozumiały jest globalny zasięg przeciwdziałania unikaniu opodatkowania, ale nie wyklucza to przecież krytycznych uwag szczegółowych.

Poza tym kontynuowana jest obserwowana od dziesięcioleci praktyka częstych zmian dokonywanych po tak krótkim okresie obowiązywania nowych rozwiązań, że nie ma możliwości należytej oceny ich przydatności. Niekiedy wiąże się to z szybko zauważonymi mankamentami redakcyjno-językowymi, co źle świadczy o poziomie przedkładanych i uchwalanych aktów prawnych.

Nawiązując do podniesionego w ten sposób wątku techniki legislacyjnej, warto zwrócić uwagę na liczne ostatnio zabiegi ukrywania nowo wprowadzonych podatków (ewentualnie innych danin). W już obowiązujących ustawach oznacza się je jako dodatkowe ich składniki, a w nowych aktach prawnych nie nazywa się podatkiem świadczenia niewątpliwie nim będącego. Konstrukcje te rażą w warstwie terminologicznej i redakcyjnej - wyjątkową sztucznością i powodują zacieranie się granic między zwykłymi nowelizacjami a poszerzaniem zakresu opodatkowania.

Nie jest uzasadniona — sama w sobie — krytyka rozrostu i postępującej komplikacji prawa podatkowego. Musi ono uwzględniać coraz większą złożoność stosunków społecznych i ekonomicznych, więc opis ich i skutków podatkowych jest coraz trudniejszy ${ }^{27}$. Tym bardziej jednak wymagać należy najwyższej staranności merytorycznej i formalnej w odniesieniu do przepisów mających sprostać takiemu wyzwaniu.

\title{
ELEMENTS OF OPINION ABOUT THE NATURE OF CHANGES IN TAX LAW
}

\begin{abstract}
Summary
Significant changes that have taken place in Polish tax law in recent years are primarily aimed at increasing budget revenues. This is done by improving efficiency and sealing the tax system by introducing new forms of burden and using subsequent taxpayer control mechanisms (including those modelled on solutions or recommendations of international importance). However, this is often done by way of frequent amendments, not based on the analysis of the effectiveness of earlier solutions, blurring the border between changes and introducing new taxes.
\end{abstract}

Keywords: tax law, changes in tax law, tax legislation

27 B. Brzeziński, O idei uproszczenia prawa podatkowego, [w:] Konstytucja, ustrój, system finansowy państwa. Księga pamiątkowa ku czci prof. Natalii Gajl, red. A. Jankiewicz, T. Dębowska-Romanowska, Warszawa 1999, s. 333-334. 


\section{BIBLIOGRAFIA}

Brzeziński B., O idei uproszczenia prawa podatkowego, [w:] Konstytucja, ustrój, system finansowy państwa. Księga pamiątkowa ku czci prof. Natalii Gajl, red. A. Jankiewicz, T. Dębowska-Romanowska, Warszawa 1999.

Etel L., Uchwały podatkowe samorzadu terytorialnego, Białystok 2004.

Filipczyk H., Postulat pewności prawa w wykładni operatywnej prawa podatkowego, Warszawa 2013.

Huchla A., Ciężary $i$ świadczenia publiczne a podatki w świetle art. 84 Konstytucji Rzeczypospolitej Polskiej, [w:] Konstytucyjne uwarunkowania tworzenia i stosowania prawa finansowego i podatkowego, red. P.J. Lewkowicz, J. Stankiewicz, Białystok 2010.

Kopyściańska K., Skwierczyńska E., Zmiany w podatku od towarów i ustug w latach 2017-2018, Wrocław 2019.

Mastalski R., Stosowanie prawa podatkowego, Warszawa 2008.

Nykiel W., Nowe przepisy dotyczace klauzuli przeciw unikaniu opodatkowania - wybrane aspekty legislacyjne, [w:] Wspótczesne problemy prawa podatkowego. Teoria i praktyka. Księga jubileuszowa dedykowana Profesorowi Bogumiłowi Brzezińskiemu, t. 1, red. J. Głuchowski, M. Kalinowski, K. Lasiński-Sulecki, W. Morawski, A. Nita, A. Olesińska, Warszawa 2019. 